\title{
HIGH ALTITUDE BALLOONING AS AN ATMOSPHERIC SOUNDING SYSTEM IN THE PRE-FLIGHT PROCEDURES OF ILR-33 AMBER
}

\author{
Marcin Spiralski, Karol Bęben, Wojciech Konior, Dawid Cieśliński \\ Łukasiewicz Research Network - Institute of Aviation \\ Al. Krakowska 110/114, 02-256 Warsaw, Poland \\ marcin.spiralski@ilot.edu.pl • ORCID: 0000-0003-2147-2026 \\ karol.beben@ilot.edu.pl • ORCID: 0000-0003-2860-8299 \\ wojciech.konior@ilot.edu.pl • ORCID: 0000-0003-4671-6664 \\ dawid.cieslinski@ilot.edu.pl • ORCID: 0000-0002-9840-6433
}

\begin{abstract}
The paper presents research on the near real-time atmospheric sounding system. The main objective of the research was the development and testing of the weather sounding system based on a weather balloon. The system contains a redundant system of radiosondes, a lifting platform containing weather balloon and a holding system as well as ground station. Several tests of the system were performed in August and September 2019. Altitude, reliability, resistance to weather conditions and data convergence were tested. During tests, new procedures for such missions were developed. The final test was performed for the ILR-33 Amber Rocket as a part of pre-launch procedures. The test was successful and allowed to use acquired atmospheric data for further processing. Several post-tests conclusions were drawn. The altitude of sounding by a weather balloon depends mostly on weather conditions, the amount of gas pumped and the weight of a payload. The launching place and experience of the crew play an important role in the final success of the mission, as well.
\end{abstract}

Keywords: weather balloon, unmanned free balloon, atmosphere sounding, radiosonde, remote sensing, Earth observation.

\section{INTRODUCTION}

Weather sounding is necessary for many areas of human activities. Weather forecasting, aviation [1], military [2] and many other weather-related activities are based on the results of such sounding. Weather forecasting uses mostly sounding data containing temperature and pressure as a function of altitude (Skew-T Log-P diagram) which gives information about wind profiles and atmospheric layers [3].

There are several ways of getting the data. The approach for getting high-resolution high altitude weather data used in the research is to adapt weather balloons for sounding purposes. It gives information about temperature, air pressure, humidity and wind speed across all the layers of atmosphere up to 40000 meters AMSL [4]. Alternative ways of atmospheric sounding are: tethered balloons [5], radar measurements [6], satellite imagery [7], rocket sounding [8,9], glidersondes [10], dropsondes (dropped from planes) [11] and recently UAVs [12]. 
Poland has a long history of weather sounding. One of the biggest and most ambitious projects before the II World War was high altitude balloon named 'The Star of Poland'. The balloon was the biggest one in the world at that time and finally, it was not launched due to the beginning of II World War [13]. Other post-war sounding projects included alternative systems, such as meteorological rockets. The most famous Polish project in the 1960s and 1970s was Meteor [8], designed by the Institute of Aviation. Even though, weather ballooning has been the most popular way of sounding. Until nowadays it has been an important part of the atmosphere research of Polish Institute of Meteorology and Water Management now: Polish Institute of Meteorology and Water Management - National Research Institute). The atmosphere parameters are cyclically measured by the Institute of Meteorology and Water Management in certain locations [7].

Weather balloons have been considered as multipurpose High Altitude Platforms (HAPs) as well as a potential High Altitude Pseudo-Satellites (HAPS). Their use has been noticed in atmosphere sounding, Earth observation [14], telecommunication [15,16], winch for stratospheric UAVs [17], as well as in innovative concepts such as space exploration $[18,19]$. A regular high-altitude ballooning system for sounding purposes contains a weather balloon, a rope (holding system) and a single radiosonde. Ground station with radio-frequency $(\mathrm{RF})$ communication for these purposes is necessary, as well as external antenna [20].

The research in the Łukasiewicz Research Network - Institute of Aviation is a continuation of the research mentioned before (rocket sounding) and its extension by meteorological ballooning. A number of tests were performed recently [9,21]. The concept of the balloon sounding system has been improved and adapted for specific purposes of the ILR-33 Amber sub-orbital rocket [24].

The main objective of the research was to design and to test the sounding system based on the weather balloon to acquire information about vertical wind profile in near real-time. The main assumption was to create reliable system which could be implemented in the pre-flight procedures of ILR-33 Amber rocket. The subsidiary assumption was to design and test more than one scheme of the sounding system, as well as performing reliability and robustness analysis.

\section{METHOD}

The requirements of the system were strictly defined. These parameters were used for the pre-flight procedures before the ILR-33 Amber launch. The system should reach cyclically the altitude of at least $15000 \mathrm{~m}$ AMSL (about 50,000 ft AMSL) to provide accurate near real-time weather data. The resultant parameters include wind speed, wind direction, altitude and time. These values could be obtained indirectly by obtaining data from the GPS which is an integral part of the radiosonde. These data were then processed in a near real-time in order to obtain the desired values. Below a description of the system, the schemes of the system and the way of data processing are presented.

\subsection{System configuration}

The first tests of the Earth imaging and atmosphere sounding system took place in 2018. System components (both hardware and software) have been reconfigured many times to optimize data acquisition, processing and visualization (Tab.1). 
Tab. 1. Configuration of the sounding system

\begin{tabular}{|c|c|}
\hline \multicolumn{2}{|c|}{ Atmospheric sounding system } \\
\hline Balloon & CPR-1200 weather balloon $1200 \mathrm{~g}$ \\
\hline Gas & Compressed helium 4.0, $25 \mathrm{I}$ tank, $4.8 \mathrm{~m}^{3}$ \\
\hline \multirow{2}{*}{ Radiosondes } & $\begin{array}{l}\text { Vaisala RS-41, frequency: } 432.500 \mathrm{MHz} \\
\text { (Firmware: STM32_RTTY by by SQ7FJB \& SQSRWU GPL v2) [25] }\end{array}$ \\
\hline & AVRT-5, frequency: $144.825 \mathrm{MHz}$ (redundant system) \\
\hline \multicolumn{2}{|l|}{ Ground Station } \\
\hline Receiver & ICOM IC-9100 \\
\hline Antenna & Dual Band Yagi, frequency: 144 / $430 \mathrm{MHz}$ \\
\hline Ground Station & Notebook with operating system Windows 764 bit \\
\hline Ground Station Software & $\begin{array}{c}\text { Balloon Atmospheric Measurements v } 1.2 \\
\text { HDSDR } \\
\text { APRSIS32 } \\
\text { SoundModem } \\
\text { Dedicated Measurement software by Institute of Aviation }\end{array}$ \\
\hline
\end{tabular}

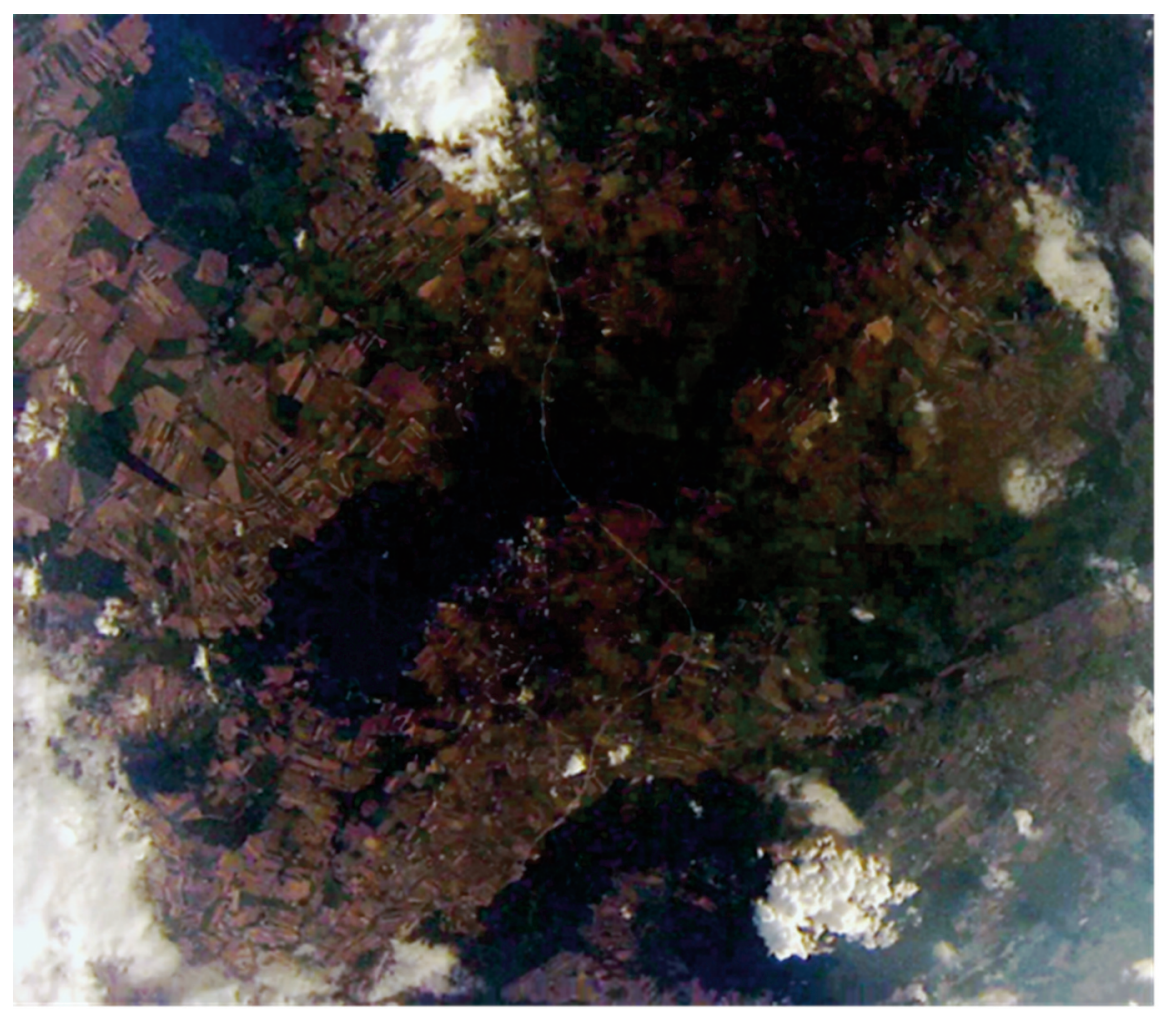

Fig 1. Imagery acquired from $25000 \mathrm{~m}$ AMSL with the use of on-board camera

At the end of 2018, the previous version of the system was developed, containing components for Earth Observation - GoPro and Quercus.2 cameras [22,23] and for near real-time data analysis (redundant sonde) and post-processing (Kestrel 5700 data logger). All elements were contained in 
a gondola weighing over 2 kilograms. The Earth observation data was successfully acquired (Fig.1), as well as meteorological data. The ground station consisted of the YAGI antenna, ICOM IC-9100 transceiver and laptop with dedicated software. The system used one frequency, so in case of failure of any communication component, data in near real-time could not be retrieved (post-processing after finding the gondola). This type of system, depending on the size of the balloon, reached altitude up to 25000 m AMSL (Fig.1). The gas selected for filling up the balloon was helium. In the following year, it was decided to modify the system, mainly related to excluding the Earth observation module and adding a backup communication module.

Radiosondes VAISALA RS-41 (frequency $432.500 \mathrm{MHz}$ ) and AVRT5 GPS tracker (144825 MHz) were selected as parts of the current redundant sounding system. The presumption to lighten the ground station by using SDRPlay RSP1A instead of ICOM IC-9100 transceiver was checked during the tests. The SDRPlay RSP1A receiver introduced large interference to the received signal, which resulted in the resignation from its use. High-quality ICOM IC-9100 transceiver, which was used during previous missions, was selected as a part of the final configuration (Fig 2).

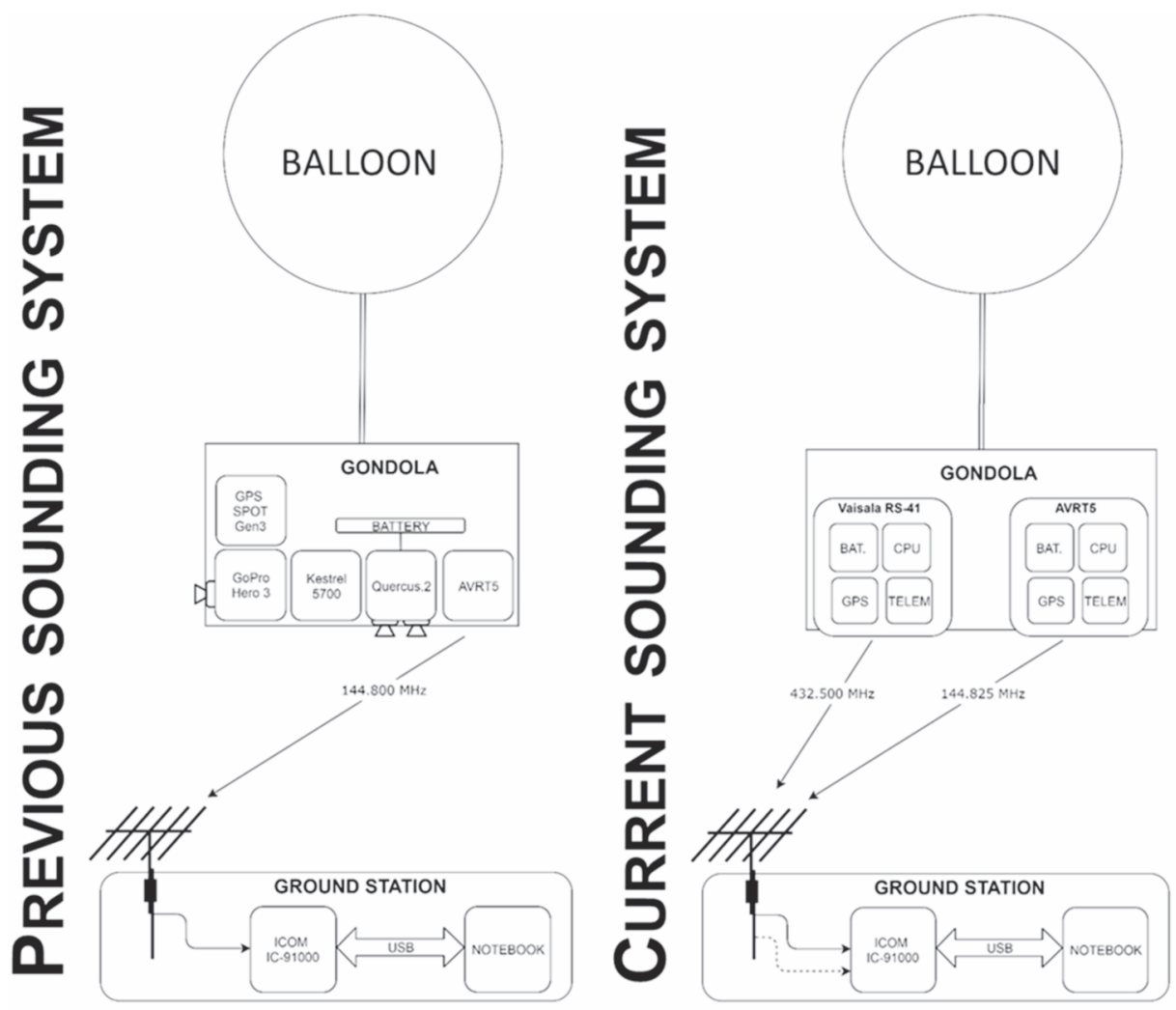

Fig. 2. Previous and current sounding system schemes

\subsection{Data processing}

Data sent from probing sondes are received at the ground station in software dedicated to automatic tracking of meteorological radiosonde. Data transmission from radiosondes is based on the Automatic Packet Reporting System (APRS). The APRS is used to determine the position of the measuring 
radiosondes using a transmitter that sends a real-time digital radio signal on the frequency of 435.500 $\mathrm{MHz}$. The telemetry reports contain information about the current position of the object. The data frame is received at a ground station at a predefined frequency. Basically, data frames are transmitted every 15-30 seconds.

Sample data frame:

2019-09-03 13:13:34 CEST: [call sign] >APZQAP, WIDE1-1, WIDE2-1,qAR,SP5QWJ-1:; [call sign] $10^{*} 111111 z 5206.67 N / 02017.10 E O / A=002197$

\section{Designations:}

- 2019-09-03 13:13:34 - current date and time;

- [call sign] - the transmission and receiving station sign;

- WIDE1-1, WIDE2-1 - signs that define packet paths;

- 5206.67N/02017.10E- geo-coordinates;

- $A=002197$ - current altitude (ft),

The data frames are decoded by the software. On the basis of the current time, appropriate conversion of the position of the radiosonde from geographical coordinates, angular and linear displacements can be calculated, the azimuth and wind direction as well as wind speed and forces. The data frames are saved in a text file. Then the file is loaded into the software and analyze. The program calculates each data frame and automatically draws a graph that shows wind speed and wind direction.

The algorithm for converting data from a frame into a graph is as follows:

- Conversion of positions from degrees and minutes to fractional part degrees:

$$
\begin{aligned}
& \varphi_{\text {coord_dec }}=\varphi_{\text {deg }}+\varphi_{\min } / 60 \\
& \psi_{\text {coord_dec }}=\psi_{\text {deg }}+\psi_{\min } / 60
\end{aligned}
$$

Where: $\varphi, \psi$ denotes longitude and latitude.

- Calculation of average latitude between new and old value:

$$
\phi=\frac{\phi_{\text {new }}+\phi_{\text {old }}}{2}
$$

- Calculating the distance of the balloon from the Earth's axis:

$$
r(\phi)=\underbrace{\left(\sqrt{\frac{\left(a^{2} \cos \phi\right)^{2}+\left(b^{2} \sin \phi\right)^{2}}{(a \cos \phi)^{2}+(b \sin \phi)^{2}}+h}\right)}_{R(\phi) \rightarrow \text { Earth's center dist. }} \cos (\phi)
$$

Where: $a, b, h$ accordingly denotes the semi-major axis, the semi-minor axis and the height above Earth's surface, all in meters. 
- Conversion of angular displacements into linear displacements:

$$
\begin{gathered}
d \psi=\psi_{\text {new }}-\psi_{\text {old }} \\
d \phi=\phi_{\text {new }}-\phi_{\text {old }} \\
d x=r(\phi) d \psi \\
d y=R(\phi) d \phi \\
d=\sqrt{d x^{2}+d y^{2}}
\end{gathered}
$$

- Calculation of azimuth and wind direction in degrees:

$$
\beta=\left(\frac{\pi}{2}-\alpha\right) * \frac{180}{\pi}+180
$$

Where: the angle is calculated as follows: $\alpha=\operatorname{arctg}(d y / d x)$. If $\beta \geq 0$, then wind direction $\beta$ is calculated as above, else the direction is $\beta+360$.

- Calculation of wind speed and acceleration:

$$
\begin{gathered}
u=-\frac{d x}{d t} \\
v=-\frac{d y}{d t} \\
w=\frac{h_{\text {new }}-h_{\text {old }}}{d t} \\
v_{x y}=\sqrt{u^{2}+v^{2}} \\
v_{\text {tot }}=\sqrt{u^{2}+v^{2}+w^{2}} \\
F_{x}=-\frac{\left(u-u_{\text {old }}\right) m}{d t} \\
F_{y}=-\frac{\left(v-v_{\text {old }}\right) m}{d t} \\
F_{h}=\frac{\left(w-w_{\text {old }}\right) m}{d t}
\end{gathered}
$$

Where: $u, v, w, v_{x y}, v_{t o t}, F_{x}, F_{y}, F_{h}$ denotes the velocity vector components, side velocity, total velocity and force vector components of the balloon, accordingly. The $m$ denotes the balloon's mass. The directions of the vectors (the signs „-" in above formulas) result from the accepted azimuth convention, which means the direction of wind speed. 


\subsection{Robustness analysis}

One of the tasks during the research was to perform reliability and robustness analysis. During 24 field tests three main parameters were measured. First of them was the ability to reach the alitude of $15000 \mathrm{~m}$ AMSL (about $50000 \mathrm{ft}$ AMSL), which is necessary for jet stream detection. The second parameter was related to received telemetry packets. The condition was met when the radiosonde provided packets all the time during flight up to demanded flight level. The third parameter was the reliability of operation regarding the operating procedures. The radiosonde fulfilled this condition when there were no unexpected failures during the flight to the demanded altitude. The assessment of reliability is presented below.

Tab. 2. Reliability assesment

\begin{tabular}{|c|c|c|c|}
\hline Radiosonde & AVRT5 & Vaisala RS-41* & Vaisala RS-41 + AVRT5 \\
\hline $\begin{array}{c}\text { Reliability of reaching } \\
\text { demanded altitude }\end{array}$ & $4 / 8$ & $7 / 8$ & $8 / 8$ \\
\hline $\begin{array}{c}\text { Received Telemetry } \\
\text { packets }\end{array}$ & $5 / 8$ & $7 / 8$ & $\begin{array}{c}8 / 8 \\
\text { Two independent } \\
\text { telemetry source }\end{array}$ \\
\hline $\begin{array}{c}\text { Reliability of operation } \\
\text { (range, configuration, } \\
\text { battery life) }\end{array}$ & $4 / 8$ & $8 / 8$ & $8 / 8$ \\
\hline
\end{tabular}

*Vaisala RS-41 with custom firmware, for details see Tab.1

The AVRT5 radiosonde during 4 tests had problems with providing data up to the required altitude. The telemetry packets could not be acquired by the ground station due to the lack of sufficient range (both horizontal and vertical). Furthermore, during some tests, the power failure was detected. That is why configuration based only on AVRT5 was rejected.

The Vaisala RS-41 was also tested 8 times. It provided accurate data to the altitude exceeding needs. During one of the tests it did not provide data to the demanded flight level what effects in subtracting one point.

The redundant configuration provided accurate and reliable data every time it was used. During all the tests such set was able to transmit data to demanded flight level. Even if one of the radiosondes stopped working, the second one was still in use and transmitted signal to the ground station. Such configuration in tests provided $100 \%$ certainty of acquiring required data.

\section{RESULTS}

Data were acquired during two types of missions - test missions in August 2019 and proper field test missions during pre-flight procedures in Ustka (just before the launch of the ILR-33 Amber). The goal of test missions was to test new configuration (including SDRPlay RSP1A) and system robustness before the proper ILR-33 Amber Rocket launch. The weather ballooning provided necessary data for the rocket starting procedures.

Data were obtained with the use of the described configuration and before every flight, a number of simulations in various sources have been performed with generally high data convergence from simulation and from the field. 


\subsection{Test missions}

Before the proper atmosphere sounding during the flight tests of the ILR-33 Amber rocket on the CPSP Ustka training ground in September 2019, it was necessary to conduct comprehensive tests of the system. Test missions were carried out in August 2019 by the Remote Sensing Division.

Further hardware and software testing were performed, as the system reliability was checked and inadequate system components were eliminated. The tests carried out have shown full readiness to reach the required altitude, reaching the 35000 meters above sea level twice. The results were confirmed by receiving a signal to the ground station as well as external sources (ex. APRS network). During the test missions, in order to check the correctness of the atmosphere probing algorithm, the data collected by our system were repeatedly compared with charts from Ventysky and Elevator services, which confirmed the convergence of the data.

During one of the missions, an unusual situation occurred. One of the balloons stabilized at a height of about $35 \mathrm{~km}$, levitating for at least 19 hours after take-off (with high probability much longer, but the data are missing due to the discharge of the battery). It was caused by the pumping the balloon with the minimal amount of helium needed for the launch (as a part of tests).

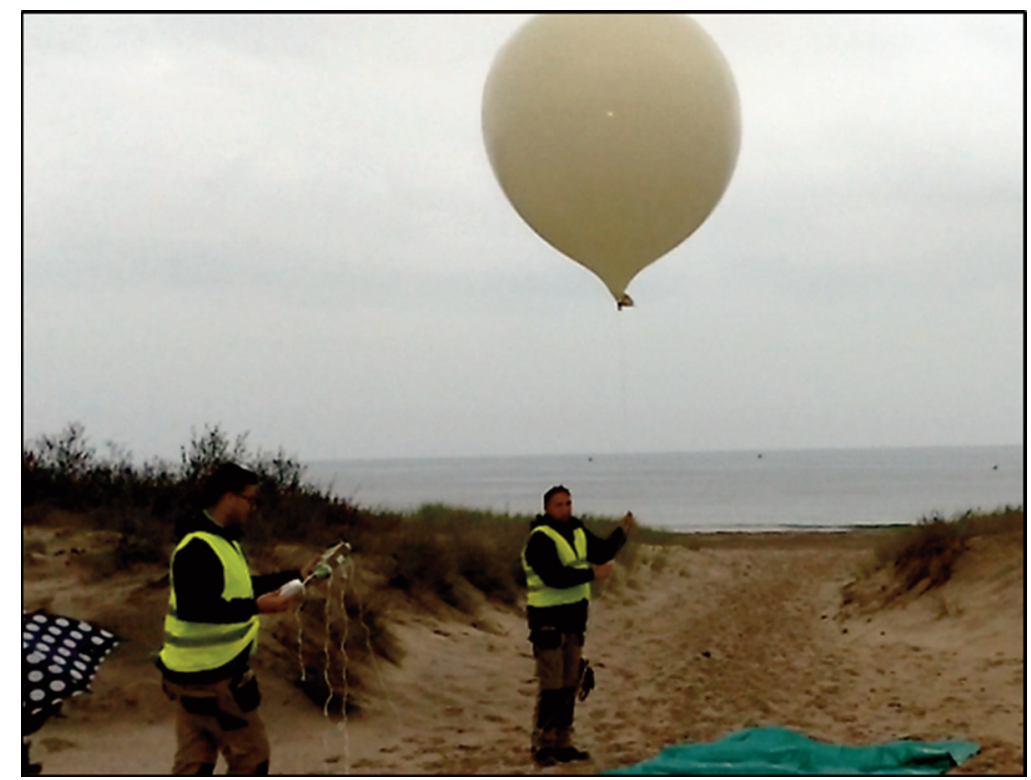

Fig 3. The moment of launching a balloon

\subsection{Field test in Ustka}

The proper rocket mission and accompanying ballooning mission took place in September 2019 in Ustka, Poland. The site was a military area located by the Baltic Seashore (Fig. 3.). The balloon launch preceded the rocket launch. The start took place in heavy rain, about $6 \mathrm{AM}$. The presumption was confirmed as the balloon reached about 15700 meters AMSL (Fig. 4 and 5.) with the same configuration that allowed to reach repeatedly $35000 \mathrm{~m}$ AMSL. The balloon at the time of the test flown the Northwest direction up to about $10000 \mathrm{~m}$ AMSL, changing direction to the North afterward (Fig. 4 and 5.). The average vertical speed of the balloon was about $5 \mathrm{~m} / \mathrm{s}$, and the side speed has changed in relation to altitude. The wind speed was increase (about $10000 \mathrm{~m} \mathrm{AMSL}$ ) but it did not threaten the rocket launch. 


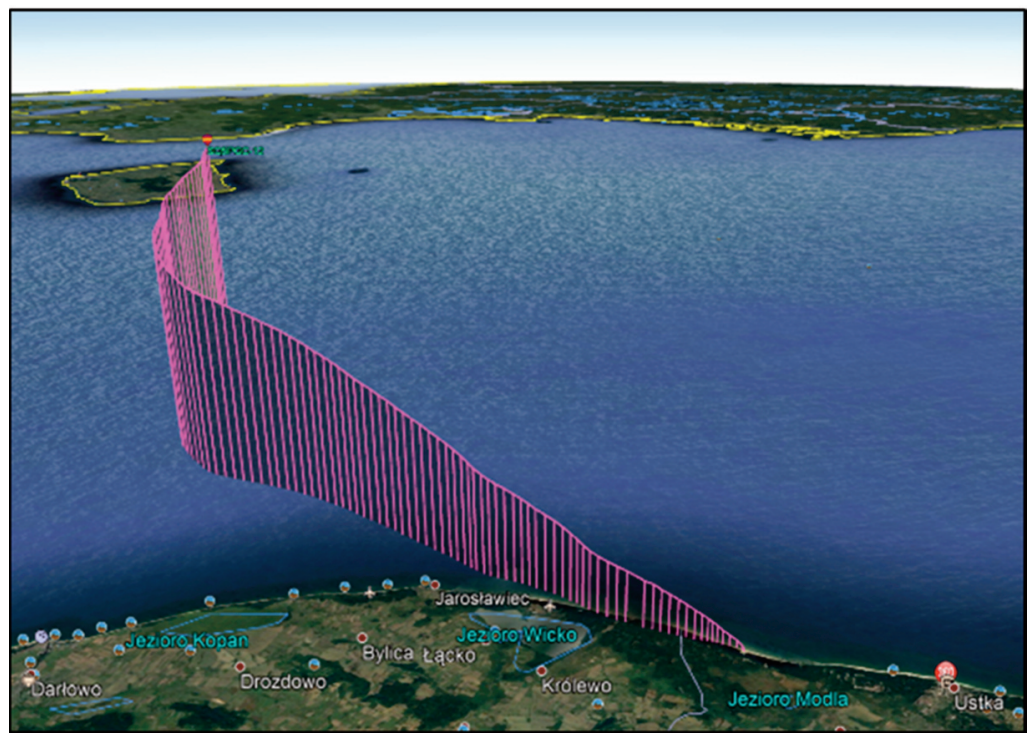

Fig 4. The route of a balloon launched in Ustka in September 2019 visualized in 3D (Google Earth).

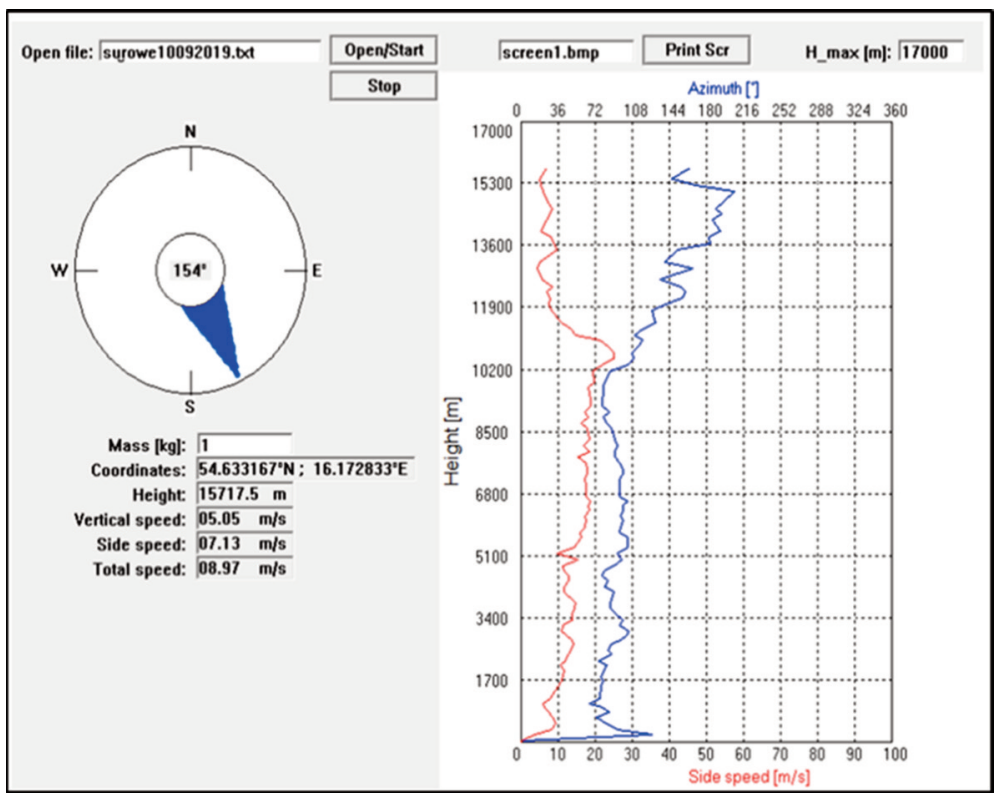

Fig.5. Diagram of Ustka ballooning test in dedicated software.

\section{DISCUSSION}

The presented system is not ideal, however, its reliability has been tested several times in operational conditions, confirming its robustness.

One of the post-test conclusion was a must to use a redundant system of radiosondes to prevent unexpected failures or detachment. Both situations have occurred during test flights, but the ability to obtain data retained in every critical situation. 
The balloon stabilization during the tests shows a certain potential for creating High Altitude Pseudosatellites (HAPS) basing on stratospheric balloons. Such a platform could be useful for observation of medium-scale areas (such as a region in a country like Poland or Germany). It could be a low-cost alternative for zeppelin-based projects like Stratobus. Such systems are already in the test phase (Stratollite from WorldView). They would preserve all the pluses of high-altitude balloons - low-cost, rapid deployability, and low-impact flight. The additional features such as an ability to navigate the platform could be added after further investigation.

Even though the test and the proper launch in Ustka were successful, a series of problems have occurred. One of them was heavy rain during the mission in Ustka. I was an unfavorable factor during the launch, resulting in lowering the maximum altitude of the system. It was a serious factor that resulted in worsening sounding parameters. The main cause of the situation was a significant weight increase due to the accumulation of droplets on the sphere of the balloon. Such conditions were not tested before by the sounding team. Therefore, no operating procedures for balloon pumping during rainstorms were created.

Another problematic issue was transmission quality and signal interference. There was a need to select the appropriate RS41 and AVRT5 transmission frequency for the data frame configuration and for the sounding configuration. It was successfully solved in the field during the tests.

A need to select appropriate batteries to provide power supply was also identified during the test. During laboratory research, many types of batteries have been tested. Parameters of most of them were not sufficient as they could not work in subzero temperatures. Finally, Energizer Ultimate batteries were selected for the final configuration due to their long-lasting and resistance to low temperature (even up to -40 Celsius degrees).

One of the problems regarding the previous configuration was a gondola recovery. It was a problematic issue, due to the need to install additional tracking devices (such as SPOT or GSM tracker) and their inaccurate GPS positioning. Another issue was a situation when there was a need to search for the device over $100 \mathrm{~km}$ from the launch site which occurred several times. If there was a need to recover devices from the gondola, a few extra hours for hard work searching for the gondola in the field had to be reserved.

\section{SUMMARY}

The weather sounding system in the described configuration proved its ability to provide repeatable, reliable and verified weather data. After a series of tests, optimal hardware components were selected, as well as the improved version of the software was developed.

The analysis of reliability of each configuration lead into the choosing the redundant configuration. The use of such radiosonde system was defined as necessary to assure the robustness of the sounding system.

Before each training ground mission, 1-2 tests of the entire system (ground equipment, balloon, radiosonde, software) should be carried out to confirm its reliability. Due to the risk of breaking the line or the radiosonde mount observed during the tests, it is recommended that at least 2 persons should inspect the attachment of the balloon line to the radiosonde to minimize the risk of the radiosonde detachment from the balloon.

Consideration should be given to extending the balloon sounding by adding a component based on wind speed and direction measurement system installed on tethered weather balloons (e. g. at altitudes of 50, 100, 150 meters AMSL) or with the usage of Multi-Rotor Unmanned Aerial Vehicles.

Test mission results show potential for projects related to High Altitude Pseudo Satellites (HAPS) in the Eukasiewicz Research Network - Institute of Aviation. A stabilized weather balloon on a certain altitude could be a useful platform for Earth observation purposes. 


\section{ACKNOWLEDGMENTS}

Great thanks to the ILR-33 Amber team members for the invitation to cooperation. Also, special thanks to Marcin Pindor for valuable advice regarding the technical issues.

\section{REFERENCES}

[1] Wolfson, M. M. and Clark, D. A., 2006, “Advanced Aviation Weather Forecasts," Lincoln Laboratory Journal, 16(1), pp. 31-58.

[2] Piontek, J., and Krzyżanowski, S., 2012, "Selected issues of meteorological preparation in artilley" Journal of Science of the gen. Tadeusz Kosciuszko Military Academy of Land Forces, 164, pp. 19-33, (in Polish).

[3] Rust, W. D., Burgess, D. W., Maddox, R. A., Showell, L. C., Marshall, T. C. and Lauritsen, D. K., 1990, "Testing a mobile version of a cross-chain loran atmospheric (M-CLASS) sounding system," Bull. Am. Meteorol. Soc., 71(2), pp. 173-180.

[4] Legain, D., Bousquet, O., Douffet, T., Tzanos, D., Moulin, E., Barrié, J., Renard, J.-B., Legain, D., Bousquet, O., Douffet, T., Tzanos, D., Moulin, E., Barrie, J. and Renard, J. B., 2013, “Atmospheric Measurement Techniques," Eur. Geosci. Union, 6(6), pp. 2195-2205.

[5] Akita, D., 2012, "Feasibility Study of a Sea-Anchored Stratospheric Balloon for Long-Duration Flights," Advances in Space Research, 50(4), pp.508-515, 10.1016/j.asr.2012.05.002.

[6] Golden, J. H., Serafin, R., Lally, V. and Facundo, J., 1986, "Atmospheric Sounding Systems," Mesoscale Meteorology and Forecasting, American Meteorological Society, pp. 50-70.

[7] Struzik P., 2008, "Meteorological satellites since 40 years in IMWM service," Nauka, 4, pp. 35-42, (in Polish).

[8] Walczewski J., 1969, “Polish Meteorological Rocket System Meteor-1," Stratos. Circ.

[9] Marciniak, B., Okninski, A., Bartkowiak, B., Pakosz, M., Sobczak, K., Florczuk, W., Kaniewski, D., Matyszewski, J., Nowakowski, P., Cieslinski, D., Rarata, G., Surmacz, P., Kublik, D., Rysak, D., Smetek, J. and Wolanski, P., 2018, “Development of the ILR-33 'Amber' Sounding Rocket for Microgravity Experimentation," Aerospace Science and Technology, 73, pp. 19-31.

[10] Douglas, M. W., Progress towards development of the glidersonde: a recoverable radiosonde system, from: http://projects.knmi.nl/geoss/wmo/TECO2008/IOM-96-TECO2008/P1(06) Douglas USA.pdf

[11] Romine, G. S., Schwartz, C. S., Torn, R. D. and Weisman, M. L., 2016, "Impact of Assimilating Dropsonde Observations from MPEX on Ensemble Forecasts of Severe Weather Events," Mon. Weather Rev., 144(10), pp. 3799-3823, 10.1175/MWR-D-15-0407.1.

[12] Reineman, B. D., Lenain, L. and Melville, W. K., 2016, “The Use of Ship-Launched Fixed-Wing UAVs for Measuring the Marine Atmospheric Boundary Layer and Ocean Surface Processes,” Journal of Atmospheric and Oceanic Technology, 33(9), pp. 2029-2052, 10.1175/JTECH-D-15-0019.1.

[13] Morgała, A., 2017, Polish star. Flight to the stratosphere 1938. Bellona Publishing House, Warsaw. Poland, ISBN 978-83-11103-368.

[14] Good, W., Mallare, B., Payne, Z., Wachs, J., Wamsley, C., Fasnacht, J., Bode, R. and Padilla, S., 2018, "Demonstration of Persistent, High Resolution Remote Sensing from an Advanced Stratollite Platform," AIAA Information Systems-AIAA Infotech at Aerospace, 2018, American Institute of Aeronautics and Astronautics Inc, AIAA.

[15] Giggenbach, D., Horwath, J. and Knapek, M., 2009, "Optical Data Downlinks from Earth Observation Platforms." Proceeding of SPIE - The International Society for Optical Engineering, 7199, 10.1117/12.811152.

[16] Malinowski, A. and Zieliński, R., 2010, "High Altitude Platform-Future of Infrastructure," Int. Journal of Electronics and Telecommunications, 56(2), pp. 191-196, 10.2478/v10177-010-0025-0. 
[17] Guérard, J., Baudin, F., Hertzog, A., and High Altitude, A. H., 2019, High altitude drones for science. Near space in the near future, from: //hal.archives-ouvertes.fr/hal-01993992

[18] Kotlarz, J. and Zalewska, N., 2019, “The Possibility of Ultraviolet Enceladus' Observations from Stratospheric Balloons," Transactions on Aerospace Research, 1(254), pp. 17-27, 10.2478/TAR-2019-0002.

[19] Hassanalian, M., Rice, D. and Abdelkefi, A., 2018, "Evolution of Space Drones for Planetary Exploration: A Review," Progress in Aerospace Sciences, 97, pp. 61-105, 10.1016/j.paerosci.2018.01.003.

[20] Won, C. H., Sale, D., Schultz, R. R., Johnson, A. F. and Semke, W. H., 2001, ”Spacecraft Systems Engineering-The Initiation of a Multidisciplinary Design Project at the University of North Dakota," Proceedings of ASEEACE, pp. 8951-8963.

[21] Skoneczny, H., 2019, "Preparation and Implementation of a Test Flight of Lightweight, Unmanned Stratospheric Balloon with GoPro Camera Mounted and Analysis of Acquired Material," Transactions on Aerospace Research, 2(255), pp. 21-32, 10.2478/tar-2019-0007.

[22] Kacprzak, M. and Rotchimmel, K., 2016, "Creating Photogrammetry Products with Photos Acquired by Array of Non-Metric Cameras," Transactions of the Institute of Aviation, 2(243), pp. 120-129, 10.5604/05096669.1205266 (in Polish).

[23] Czapski, P., Kacprzyk, M., Korniluk, T., Kotlarz, J., Kubiak, K., Mazur, A., Mrowiec, K., Oszako, T., Pieniążek, J., Pośpieszczyk, A., Tkaczyk, M., Wodziński, K. and Zalewska, N., 2014, "Design and application of multisensory platform for the studies of selected environment characteristics," Transactions of the Institute of Aviation, 1(234), pp. 126-142, (in Polish).

[24] Pakosz Michał, Bartkowiak Bartosz, Cieśliński Dawid, Noga Tomasz, Okniński Adam, 2019, "ILR-33 Bursztyn as a missile technology test platform" in: Challenges and development of air defense of the Republic of Poland. Defense of the Republic of Poland of the 21st century. Military University of Aviation, Dęblin, Poland, ISBN 978-83-64636-88-2, (in Polish)

[25] https://github.com/SQ7FJB/RS41 balon sq7fjb [Accessed: 17-Dec-2019]

\title{
BALON METEOROLOGICZNY JAKO SYSTEM SONDOWANIA ATMOSFERYCZNEGOW PROCEDURACH PRZEDSTARTOWYCH ILR-33 BURSZTYN
}

\begin{abstract}
Abstrakt
W artykule przedstawiono badania nad systemem sondowania atmosferyczny w czasie zbliżonym do rzeczywistego. Głównym celem badania było stworzenie oraz testowanie systemu sondowania atmosfery opartego o balony meteorologiczne. W skład systemu wchodzi redundantny system radiosond, platforma nośna zawierająca balon meteorologiczny i system mocujący, a także stacja naziemna. W sierpniu i wrześniu 2019 r. przeprowadzono kilka testów systemu. Badano wysokość, niezawodność, odporność na warunki atmosferyczne i zbieżność danych z innymi źródłami. Podczas testów opracowano nowe procedury dla misji tego typu. Końcowy test został przeprowadzony dla rakiety ILR-33 Bursztyn w ramach procedur przedstartowych. Test zakończył się sukcesem i umożliwił wykorzystanie pozyskanych danych atmosferycznych do dalszego przetworzenia. Wyciągnięto kilka wniosków po testowych. Wysokość sondowania osiągana przez balon meteorologiczny zależy głównie od warunków pogodowych, ilości wtłoczonego gazu i masy ładunku użytkowego. Miejsce startu i doświadczenie załogi odgrywają również ważną rolę w końcowym sukcesie misji.
\end{abstract}

Słowa kluczowe: balon meteorologiczny, sondowanie atmosfery, radiosonda. 